\title{
Effectiveness of carbohydrates as a functional ingredient in glycemic control
}

\author{
Fabiana Andrea Hoffmann SARDÁ ${ }^{1,2,3}$, Eliana Bistriche GIUNTINI ${ }^{2}$, Julie-Anne NAZARE ${ }^{4}$, Daniel KÖNIG \\ Luciana Ribeiro BAHIA ${ }^{6}$, Franco Maria LAJOLO $^{1,2 *}$, Elizabete Wenzel de MENEZES ${ }^{2}$
}

\begin{abstract}
High postprandial glycemia in the non-diabetic population is one of the known universal mechanisms for the progression of noncommunicable diseases (NCDs), which have impacted the finances of both individuals and of health systems. In order to highlight the role of carbohydrates in glycemic control and its implications on health, the International Life Sciences Institute Brazil held an international workshop on "Carbohydrates, Glycemia and Health". Carbohydrate digestion rate is related to glycemic response, which mainly depends on the quality and amount of carbohydrate ingested, and thus it may be modulated by intrinsic and extrinsic factors. These effects can be verified by using different methods which evidence how physiology adapts in the uptake of glucose. Consumers can be aided with the knowledge/awareness of the benefits of high postprandial glycemia control in non-diabetic subjects. Multisectorial actions can contribute to decrease the onset and worsening of NCDs. A strategy indicated to the public in general to expand the availability of products that do not result in a sudden increase of postprandial plasma glucose and/or insulin would be to use alternative ingredients and/or technology in addition to making the legally allowed communication of benefits, which are supported by scientific studies.
\end{abstract}

Keywords: slowly available carbohydrates; resistant starch; fiber; food.

Practical Application: This review highlights how the actions of multiple agents can contribute to decrease the onset and worsening of NCDs based on the importance of controlling high postprandial glycemia in non-diabetic subjects. There is solid knowledge about ingredients with this potential, but it is necessary to increase their use in the development of new products with low glycemic load, as well as to efficiently communicate these benefits to the consumer.

\section{Introduction}

The nutritional importance of carbohydrates has always been related to the supply of energy for the human body. In the last 50 years, that has changed a lot. It is known today that carbohydrates play an important role in health which goes far beyond the energy function and has a number of positive physiological effects related to a decrease in the risk of noncommunicable diseases (NCDs).

Studies on carbohydrates, from the viewpoint of their biological utilization, mainly started with dietary fiber (DF) and the interest in its physiological effects; this fact is reflected in the increase of scientific publications in the last decades. According to a survey performed in PubMed, using specific keywords (Dietary fiber, Definition, Concept, Analysis, Methodology, Claim and Consumer), it is noteworthy that until 1970 there were only 820 published articles; in the 80 s that number increased to 3075 ; in the 90 s to 4443 and in the decade of 2000 to 5616 articles (Menezes et al., 2013). Among 2010 and 2015, 4702 scientific articles had already been published. This progress reflects the participation of DF in human health, considering its composition, structure, physicochemical properties, and physiological effects, among other properties. Currently, DF, represented by different compounds, is one of the main ingredient used in functional foods.

Carbohydrates are made up of compounds of varying composition, structure and biological utilization that are distinctly digested and absorbed. It is known today that, among the available carbohydrates, there are the rapidly and slowly digested carbohydrates, which have different impact on physiology.

The carbohydrate digestion rate can modulate the glycemic response, which mainly depends on the type and amount of carbohydrate ingested. Despite the intermittent supply of glucose during the night and day, plasma glucose is strictly controlled and remains relatively stable in healthy subjects throughout the day, oscillating within a narrow range of $4-10 \mathrm{mmol} / \mathrm{L}$, which allows continuous supply to the organs that are solely dependent on glucose. This glucose homeostasis requires the coordinated action of several organs, and requires the modulation of four mechanisms: intestinal absorption of exogenous glucose, production of endogenous glucose, utilization of glucose by insulin-dependent and by non-insulin dependent tissues. Although 
the connection between cardiometabolic diseases and fasting metabolism has been extensively studied, it is equally important to examine how metabolic parameters in the postprandial phase are related to lipotoxicity and glucotoxicity (Blaak et al., 2012; Laville et al., 2013). The multiplication of hyperglycemic and hyperinsulinemic postprandial peaks could be directly linked to cardiometabolic complications. Therefore, it is very important to study how a particular type of carbohydrate could modulate postprandial plasma glucose and have a potential beneficial effect.

The application of this carbohydrate-related knowledge through actions in conjunction with the food industry and the population could minimize the high costs to the health system related with treatment and hospitalization due to worsening of NCDs.

\section{Prevalence and economic and clinical impact of NCDs}

The World Health Organization considers that the human, social and economic consequences of noncommunicable diseases are serious in every country and can be devastating to poor and vulnerable populations. NCDs are the main cause of mortality in the world, in 2012 they accounted for $68 \%$ of a total of 56 million deaths. Approximately 28 million deaths have resulted from these diseases, $82 \%$ of which are considered premature deaths (before the age of 70) and occurred in low- and middle income countries. In these countries, the cumulative economic losses due to NCDs were estimated at US\$7 trillion from 2011 to 2025 (World Health Organization, 2014). These diseases include cardiovascular diseases and cancer in addition to obesity and diabetes and account for $72 \%$ of the mortality rate in Brazil (Schmidt et al., 2011).

In 2014 , approximately $39 \%$ of the adult population was overweight and $13 \%$ was obese and the highest prevalence was seen in the American continent, followed by Europe and the Western Pacific region (World Health Organization, 2016a). A study conducted on more than 14,000 individuals from 16 countries in Europe identified $47.6 \%$ obese or overweight individuals (54.5\% men and $40.8 \%$ women), being more prevalent in Northern Europe and less prevalent in the Western and Southern regions of Mediterranean countries, ranging from $7.6 \%$ in Italy to more than $20 \%$ in Croatia and England. It was also observed that obesity increases with age and decreases with the level of education (Gallus et al., 2015).

In 2014, in Brazil the percentage of overweight individuals reached $52.2 \%$ of the adult population, $58.3 \%$ of which were men and $45.4 \%$ were women. Obesity showed a frequency of $16.5 \%$ among men with a trend to increase up to 44 years of age, and $15.5 \%$ among women with an upward trend up to 54 years of age (Brasil, 2015).

Obesity and overweight are often related to other diseases such as hypertension, dyslipidemia and diabetes. Diabetes is a disease with high and growing prevalence with a high social cost and high morbidity and mortality rates. According to the World Health Organization (2016b), 1 in every 11 adults has diabetes adding to a total number of 422 million individuals in April 2016, a number which has increased four times since 1980.
In Brazil, 2014 data show that among the interviewed population aged 55-64 years, 14.9\% reported having been diagnosed with diabetes by a physician and in the individuals over 65 years this percentage rose to $24.4 \%$ (Brasil, 2015).

Diabetes is characterized by chronic hyperglycemia, can cause damage to several organs such as the kidneys, eyes, heart and blood vessels; and, is one of the main causes of renal failure, lower limb amputation, blindness and cardiovascular disease (Forbes \& Cooper, 2013). The increase in prevalence is associated with the increase in overweight and obesity and also with urbanization, including poor eating habits such as with high energy content diets, large food portions and high intake of saturated fats and sugars and a reduced intake of dietary fiber (Ley et al., 2014).

\subsection{Spending on obesity/overweight and diabetes}

The economic impact of diabetes includes both the cost of the health system as the cost of the individual. In 2012, it was estimated that in the US the costs associated with diabetes and pre-diabetes was at US\$ 176 billion in relation to medical treatment costs and at US\$ 69 billion for indirect costs due to the inability to work disability and loss of productivity (American Diabetes Association, 2013).

A study conducted in approximately 700,000 cases of diabetes in Canada from 2004 to 2012 identified a cost of about C\$2,800 in the year of diagnosis, that increases substantially with age. According to the authors spending is excessive and it is a challenge for management because it implies ensuring a sustainable health system for an aging population and for other existing risk factors such as obesity (Rosella et al., 2016).

In a study conducted by Li et al. (2015) a positive association was observed between health care costs (sum of outpatient costs, hospitalization and medication) and the mass body index (BMI) associated with three levels blood glucose (normal, pre-diabetes and diabetes). Costs associated with high BMI compared with subjects with a normal BMI ranged from US\$ 336 to US\$1,850 for obesity class III (over $40 \mathrm{~kg} / \mathrm{m}^{2}$ ) in subjects with normal levels of blood glucose. Among those with pre-diabetes the variation between a normal BMI and obesity class III was US\$ 792 to US\$2,434. Costs ranged from US\$ 1,139 in overweight to US\$ 4,649 in obesity class III for a diabetes stage.

In Brazil, hospital expenses with diseases associated with the presence of overweight and obesity (diabetes, hypertension, stroke, coronary heart disease, some types of cancer among others) are in the order of US $\$ 2.1$ billion, where US $\$ 1,4$ billion is accounted for hospitalizations. Obesity was associated with $66.4 \%$ cases of diabetes (Bahia et al., 2012). A study conducted in 8 cities with 1,000 patients with diabetes under different standards of care estimated total cost of US\$2,108 patient/year of which $63.3 \%$ was of direct costs and $36.7 \%$ of overhead. It is important to highlight that costs rise with the longer the duration of the disease and its resulting complications (Bahia et al., 2011).

Similarly to what occurs in these countries the costs related to these diseases also burden both the public and private systems in Brazil, as well as representing a high cost for society and 
should be considered in public policy proposals, which should involve the various sectors of society.

Among the modifiable risk factors for NCDs are physical inactivity and poor nutrition, which should be given special attention in the definition of public policies and raise the interest of the food industry. The WHO considers that food labeling can be useful in guiding consumers thus contributing to healthy eating habits and that in association with educational actions on environmental and/or nutritional aspects it can be effective in changing consumer behavior and the standards of food consumption (World Health Organization, 2014). Healthy eating habits should be encouraged in several ways which also includes establishing agreements with the food industry to lower the content of salt, fats and sugar in processed foods.

\section{Carbohydrate: definition and classification}

Carbohydrates can be classified in several ways. The chemical classification of carbohydrates (determined by the degree of polymerization (DP), bond type ( $\alpha$ and non- $\alpha$ ) and type of monomer is based on the proposal of the Food and Agriculture Organization of the United Nations (1998). Carbohydrates are classified into three classes: sugars (DP $=1$ or 2), oligosaccharides (DP 3-9), and polysaccharides (DP $>9$ ), whereby each class presents the following subclasses: monosaccharides, disaccharides, and polyols; malto-oligosaccharides, and other oligosaccharides; starch, and non-starch polysaccharides, respectively. Livesey (2003) suggested that sugars should be separated from polyols; since polyols are not sugars, they may be used in "sugar-free" or "tooth-friendly" products and promote a decrease in postprandial glycemic response (European Food Safety Authority, 2011b; Livesey, 2003).

Carbohydrates can also be classified according to their digestibility in the body. Unavailable carbohydrates are those that resist digestion in the small intestine or are poorly absorbed and/or metabolized. The term unavailable carbohydrates is equivalent to resistant, non-digestible carbohydrates (Englyst et al., 2007) or dietary fiber (DF). DF has local effects, promoting a delay in gastric emptying, in starch digestion and glucose absorption, and reduction of the intestinal transit time due to the increase in volume (Jones, 2014; Klosterbuer et al., 2011). Some of these carbohydrates can be fermented in the large intestine by the intestinal microbiota (Dan et al., 2015; Licht et al., 2012; Roberfroid et al., 2010). Fermentation increases fecal bulk, modifies the $\mathrm{pH}$ of the colon, and produces gases and short chain fatty acids (SCFA), which are absorbed into the portal system and carried to the liver and peripheral tissues. Some unavailable carbohydrates are called prebiotic carbohydrates because of their metabolism by intestinal microorganisms, modulating the composition and/or activity of the intestinal microbiota, which thus confers a beneficial physiological effect on the host (Bindels et al., 2015; Food and Agriculture Organization of the United Nations, 2008).

Available carbohydrates can be classified according to their hydrolysis rate and can be divided into rapidly digested disaccharides (sucrose, lactose, maltose); slowly digested disaccharides (isomaltulose); rapidly (maltodextrin) and slowly digested oligosaccharides (resistant maltodextrin), rapidly and slowly digested polysaccharides (starch - dependent on the supply, treatment, or other factors) (Englyst et al., 1999, 2003; Lajolo \& Menezes, 2006; Livesey, 2003). According to Englyst \& Hudson (1996), the starch present in foods can be divided into three types, according to the incubation time with specific enzymes: slowly digestible starch (SDS), rapidly digestible starch (RDS) and resistant starch (RS). Similarly, Englyst et al. (1999) defined as rapidly available glucose (RAG) the carbohydrate that is released after $20 \mathrm{~min}$ of incubation with amyloglucosidase, and slowly available glucose (SAG) the carbohydrate that is released after $120 \mathrm{~min}$ of incubation.

Regarding available polysaccharides, these can be divided into RDS and SDS. Different factors can interfere with digestion and utilization of starch from food and can consequently change the postprandial glycemic response. One of these factors is food technological processing and/or cooking that can affect, for example, the degree of gelatinization of the starch, degree of crushing, cell structure and starch retrogradation. In vivo studies in mice, and in vitro and microscopy studies show that when beans are cooked or processed, a partial starch gelatinization takes place due to the presence of the cell wall, which protects the starch from swelling and gelatinization, thus hindering the action of alpha-amylase and providing slow digestion of the starch (Menezes \& Lajolo, 1995). This study highlights the importance of the need to maintain the integrity of the cell structure of the cell wall to hinder the digestion of the starch.

As well as the classification, the terminology applied to carbohydrates is being suggested and adopted over time, but it has generated controversy. The most mistaken one, which is still used by some professionals, is the separation of simple carbohydrates from complex carbohydrates. The term "complex" was first used in 1977 to distinguish carbohydrates present in plants in general, especially whole grains, from sugars (glucose, fructose and sucrose), and became associated with starch and other polysaccharides. However, fruits and vegetables have a low starch content (Cummings \& Stephen, 2007) and, in parallel, it was found that there are different types of starch part of which is digested and absorbed quickly, producing high glycemic response, the same as sugars produce (Jenkins et al., 1981; Lajolo \& Menezes, 2006). Thus, the term "complex" may not reflect the true digestibility of carbohydrates and should not be used (Cummings \& Stephen, 2007; Food and Agriculture Organization of the United Nations, 2003). In 2003, FAO recommended the 'available carbohydrate' designation for carbohydrates that can be digested by human digestive enzymes, absorbed in the intestine and that are involved in energy metabolism, which includes not only soluble sugars but also available starch.

Regardless of the definition adopted, it is carbohydrate digestion and absorption rate that are directly related to the width of plasma glucose peaks, which can contribute or reduce the risk of NCDs. Rapidly absorbed carbohydrates cause a sudden increase in plasma glucose, while the slowly digested carbohydrates, regardless of the size of the molecule, provide a moderate increase in plasma glucose and insulin after meals rich in carbohydrate. Therefore low-release carbohydrates provide 
a slow and sustained release of blood glucose (Menezes et al., 2010; Vinoy et al., 2013; World Health Organization, 2003).

\section{Glycemic response evaluation}

The glycemic index (GI), was introduced in 1981 (Jenkins et al., 1981) and aims to classify food according to the postprandial glycemic response (increasing of blood glucose concentration $2 \mathrm{~h}$ after a meal) produced by a carbohydrate ( 25 or $50 \mathrm{~g}$ ) from a studied food compared with the reference food. The experimental protocol for the evaluation of food's GI was defined by FAO/WHO (Food and Agriculture Organization of the United Nations, 1998) and widely discussed by field experts (Brouns et al., 2005). Considering glucose as the reference food (100\%), foods are classified as follows: low GI ( $\leq 55 \%)$; medium GI (56-69\%); high GI ( $\geq 70 \%)$.

The concept of glycemic load (GL) was introduced in 1997 (Salmerón et al., 1997) and aims to relate the glycemic response of a diet as a whole, not just the amount of carbohydrate ingested, with the risk of emergence of NCDs. GL is defined as the product of the food GI by the amount of available carbohydrate present in the portion consumed, divided by 100 [GL = GI (glucose as reference) $\times$ available carbohydrate content $(\mathrm{g})$ in the portion $x$ 1/100] (Liu et al., 2000; Ludwig, 2003). The reference values used for classification of food as to GL (considering glucose as the reference food) are low GL ( $\leq 10)$; medium GL (11-19); high GL $(\geq 20)$ (Harvard School of Public Health, 2013).

Several in vitro methods have been proposed to assess the starch hydrolysis rate in order to predict the glycemic response to be produced. From the in vitro hydrolysis kinetics of food (carbohydrate source), the hydrolysis index (HI) can be calculated and hydrolysis products can be quantified according to the incubation time with amyloglucosidase (Englyst \& Hudson, 1996; Englyst et al., 1999; Goñi et al., 1997).

In Brazilian foods, Rosin et al. (2002) found a significant correlation between HI and RDS in cooked foods, with and without storage $\left(20^{\circ} \mathrm{C} / 30\right.$ days $)$, on dry base, and suggested the $\mathrm{RDS}$ as an additional parameter for evaluating the digestibility of the starch. However, there was no correlation in the whole base, possibly due to the variability of the food's solids content.

In vivo data showed significant positive correlation between GI values in humans (Carreira et al., 2004) and RDS (Rosin et al., 2002) from nine foods $(y=1.97 x+0.76 ; r=0.893 ; p \leq 0.001$; $\mathrm{n}=9$ ). In parallel, a significant positive correlation between the GI values in animals and SDS from 31 foods was also observed $(\mathrm{y}=2,190 \mathrm{x}+5,21 ; r=0,776 ; \mathrm{p} \leq 0,001 ; \mathrm{n}=31$ (Lajolo \& Menezes, 2006). In this context, we notice that the type of food and its processing are directly related to both the GI and the RDS content, expressed on dry basis. White bread is an example of a processed food, which starch is fully gelatinized, which enables its fast digestion/absorption, producing high GI and increased RDS content. In legumes and low-processed cereal grains, the starch is encapsulated by the cell wall, which slows its digestion/absorption, and they have decreased values of SDS and, accordingly, low GI. Thus, SDS is a marker that reflects the reduced glycemic responses that foods will produce, and it can be used for preliminary screening of foods that are sources of starch (Lajolo \& Menezes, 2006).

Englyst et al. (1999) observed a high positive correlation was noticed between the RAG content and GI values, when four foods were evaluated (pasta, bread, corn flakes and barley. In another study the contents of RAG, SAG, GI, and insulin index (II), in 23 cereal products, concluded that the high SAG content can identify low-GI foods, since they are rich in slow-digesting carbohydrates (Englyst et al., 2003).

Using the in vitro method (Englyst \& Hudson, 1996) in cereal products, a relationship between SDS content and decreased postprandial glycemic response was observed, with no disproportional increase in insulin response (European Food Safety Authority, 2011a). In parallel, Garsetti et al. (2005) evaluated the relationship between GI e insulin index (II), in vivo, and in vitro digestibility - RAG and SAG - from 24 types of plain sweet crackers. The authors concluded that these crackers have low GI and moderate GI and these characteristics are correlated to in vitro digestibility, and are dependent on the processing type.

The in vitro methods for assessing carbohydrate digestion rate showed good correlation with the glycemic response from foods, a fact that turn them alternative markers for a preliminary screening of foods as to its possible effect in vivo. However, according to Nantel (2003), these parameters cannot be used as GI surrogates, because only in vivo assays may reflect part of the metabolic responses that occur in the human body with carbohydrate intake.

A new methodology in vitro-in silico, considered more economic, was recently tested to safely predict the human glycemic curve after ingestion of 22 different products or meals. It was developed and validated with a combination of in vitro chewing of food, carbohydrate digestion and availability for absorption of glycemic saccharides. After, using in vitro data as input, in silico prediction of glycemic response curves were performed and they were compared with clinical data. The results showed a correlation coefficient for area below the 120 min glucose curve and maximum glucose concentration of 0.89 and 0.94 , respectively (Bellmann et al., 2018).

Glycemic response is not only determined by the absorption rate of glucose from foods, but it also depends on the endogenous glucose that is produced and, on the glucose taken up by the tissues. Thus, the increase of glucose in the systemic circulation and the glycemic response from a starchy food product is not always correlated (Eelderink et al., 2012a), depending on the balance between absorption, production and uptake. Therefore, the postprandial peripheral markers are only partially based on the absorption kinetics of starch-derived glucose (Nazare et al., 2009; Normand et al., 2001).

Using stable isotopes of glucose allows to follow the kinetics of exogenous glucose coming from a meal and the kinetics of endogenous glucose production and to distinguish these mechanisms underlying postprandial glycemia variations. For 20 years, a team of expert researchers has pioneered the use of double labeling of glucose to investigate the fate of carbohydrate ingestion (absorption, uptake and oxidation) (Nazare et al., 2009; Normand et al., 2001; Shrout \& Fleiss, 1979). The measurement 
of ${ }^{13} \mathrm{C}$-glucose enrichment in plasma by mass spectrometry coupled with gas chromatography, together with mathematical modeling allows the fate and postprandial kinetics of exogenous ingested starch, total glucose and endogenous glucose production to be followed.

Although there is a good correlation between in vitro starch digestibility and postprandial plasma glucose and insulin responses, the ingestion of two products with the same GI may result in different postprandial metabolic regulatory processes. A decrease in the glycemic response may result from a decrease in glucose uptake and/or increase in peripheral glucose uptake and this could lead to differential effects on other metabolic parameters. It is noteworthy that the changes that occur during the postprandial period are longer than the $2 \mathrm{~h}$ of the GI study and concern at least $4 \mathrm{~h}$ after ingestion of the meal.

The delay and length of the postprandial phase of the glycemic response have different and distinct metabolic consequences than the decrease in the response itself, acting on insulin kinetics. Taking into consideration the overall glucose kinetics, as well as hormonal and lipid responses, provides deeper insights into the effects of carbohydrates in metabolic control during all day, the availability of nutrients and their oxidation, and finally on the cardiometabolic risk profile.

\section{Importance of glycemic control and moderate glycemic response in health}

The main dietary determinants of postprandial plasma glucose are the amount and type of carbohydrate ingested, including its composition, nature and digestibility, culinary and technological treatments to which they were submitted, which could affect their bioavailability. The composition of the concomitant or previous meal and the association with other nutrients such as lipids or proteins can also be decisive (Gunnerud et al., 2012; Normand et al., 2001). All these factors can change the glycemic response differently, acting on gastrointestinal factors (gastric emptying or intestinal absorption) and hormonal factors such as insulin, glucagon, intestinal hormones, incretins.

Low-GI diets, low-GL or reduced glycemic response have beneficial effects on various metabolic and physiological aspects involved in NCDs (Barclay et al., 2008; Buyken et al., 2010; Chiu et al., 2011; Food and Agriculture Organization of the United Nations, 1998; Goff et al., 2013; Kolb \& Mandrup-Poulsen, 2010; Livesey et al., 2013; Schaafsma \& Slavin, 2015; World Health Organization, 2003), and these effects can be extrapolated to diets with slow-digesting carbohydrates, since low-GI foods usually contain a high content of this fraction.

The digestion process of carbohydrates involves a series of steps, from chewing, gastric emptying, digestion, and absorption in the enterocytes of the small intestine to the penetration of monomers into the bloodstream; process that result in changes in plasma glucose levels. The hyperglycemia state can be a risk factor for the development of several metabolic changes. Insulin resistance begins with reduced insulin secretion, insufficient to control blood glucose derived from the diet, which causes postprandial hyperglycemia that causes endothelial dysfunction. In the postprandial period there is release of acetyl CoA, a result of metabolism of carbohydrates and lipids, which combine with oxygen in the mitochondria, resulting in the generation of ATP molecules and charged particles of free radicals. When there is overload of acetyl-CoA, due to excess consumption of food there is greater generation of free radicals. This oxidative stress may be the latent mechanism of resistance to insulin, diabetes and cardiovascular disease (Augustin et al., 2015).

When compared to alpha-glucosidase inhibitors, used as a drug to slow digestion and absorption of carbohydrates, low GI or CG diets have the same potential in reducing the risk of developing type 2 diabetes and cardiovascular disease, similarly reducing glycemia and postprandial insulinemia. Furthermore these diets are more effective in decreasing insulin resistance and body fat (Augustin et al., 2015).

The hyperglycemia occurs in diabetes mellitus, and can occur in healthy individuals. The results of the meta-analysis of 37 observational studies performed by Barclay et al. (2008) support the premise that a high postprandial glycemic response is a mechanism related to the progression of some NCDs. For this reason, it is believed that is convenient to reduce the extent and duration of postprandial hyperglycemia (Saris et al., 1998). In patients with diabetes, reductions in glycated hemoglobin (HbA1c) levels have been observed with low GI diets, and in animals studies high GI diets caused damage to pancreatic islet cells (Augustin et al., 2015). In a study by Ferrannini et al. (2005), the beta cells sensibility to glucose decreased linearly to increasing glucose for $2 \mathrm{~h}$. Insulin tolerance was reduced between healthy and obese individuals with normal glucose tolerance, but the reduction was even greater between glucose intolerant and type 2 diabetes patients. The authors concluded that $89 \%$ of the 2 -h glucose variation can be explained by the insulin sensitivity and beta cell function, independently.

In a review prepared by Buyken et al. (2010), the authors concluded that there is consistent evidence that a food strategy for reducing the risk of developing type 2 diabetes includes reducing the glycemic and insulinemic postprandial response, recommending the adoption of a healthy diet, like the Mediterranean, and diets with low GI and GL. Figure 1 shows possible mechanisms relating the high CG diets intake, hyperglycemia and the development of type 2 diabetes.

In another review, Chiu et al. (2011) found an association between the risk of type 2 diabetes and high GI diets in 7 of 11 prospective epidemiological studies, and also the association between risk of type 2 diabetes and high glycemic load for 6 of 10 studies. With daily replacement of small amounts of white bread or potatoes by low-GI foods, especially those containing whole grains, it is possible to migrate from high- to low-risk group for macular degeneration. The authors emphasize that the population could be instructed to use the GI to select their food, aiming to reduce the risk of developing type 2 diabetes, cardiovascular diseases and age-related eye diseases, since the concepts and methods related to this marker have shown consistent results.

These observations feed into a broader global issue of how the best relevant markers of postprandial plasma glucose relate to health benefits. Modulating the digestibility and bioavailability of glucose has effects that go far beyond those that can be observed 


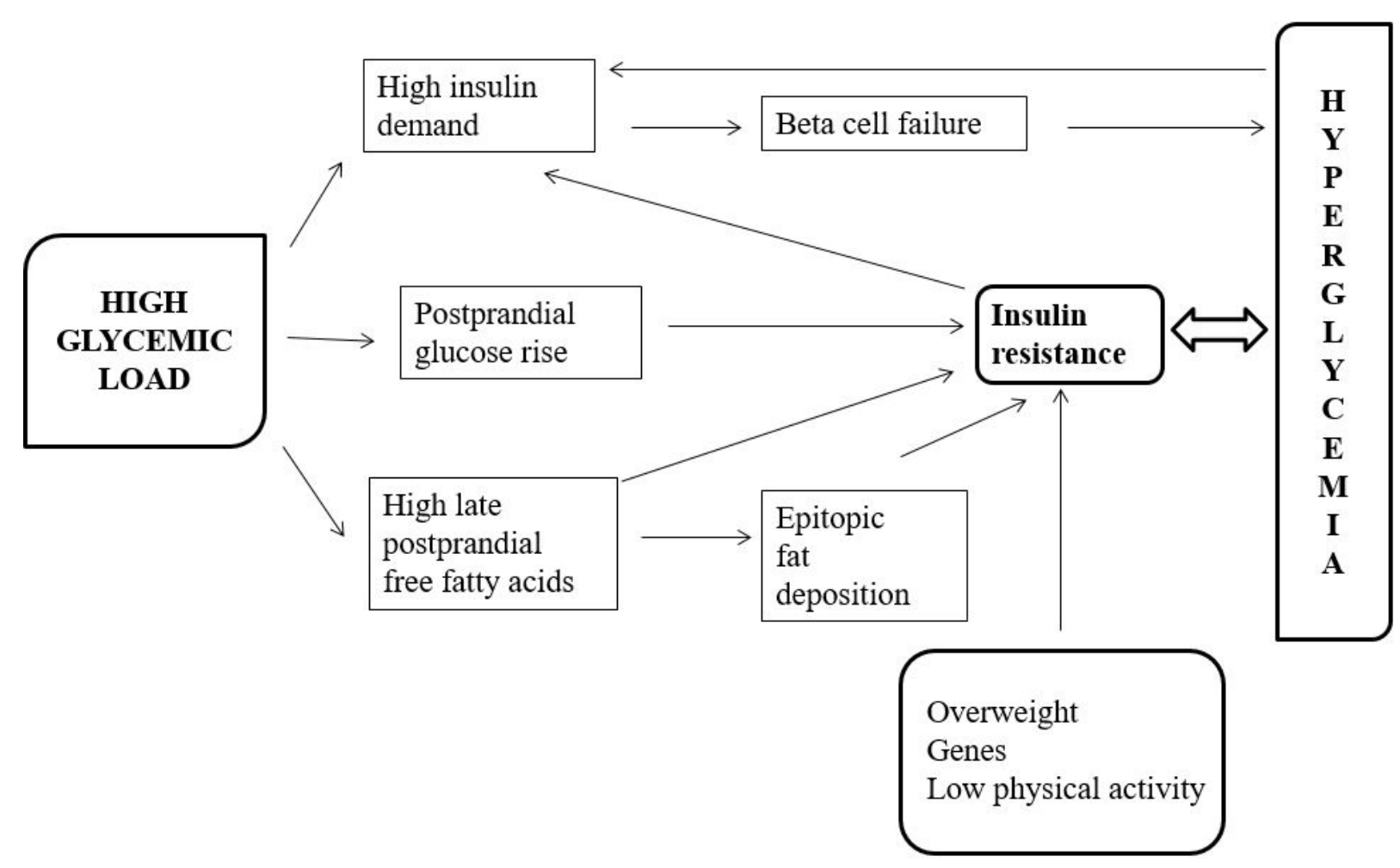

Figure 1. Possible mechanism between the consumption of high glycemic load diets and the development of diabetes-related hyperglycemia. Adapted from Riccardi et al. (2008) and Nayak et al. (2014).

with a simple 2-hour plasma glucose post-meal follow-up (Laville et al., 2013).

The International Carbohydrate Quality Consortium (ICQC), which brings together renowned carbohydrate experts, defined their position about the use of information on glycemic response. They state that there is a consensus that low GI and CG diets are important for reducing the risk of developing diabetes and coronary disease and probably obesity and are particularly important in individuals with insulin resistance. ICQC also considers that it is urgent to communicate information on GI and CG to the general public and health professionals through food guidelines and national guidelines, food composition tables and food labels (Augustin et al., 2015).

\section{Carbohydrates as a functional ingredient in glycemic control}

The different glycemic responses produced by food are due to the presence of certain intrinsic and extrinsic factors of foods that affect the hydrolysis and absorption rates of carbohydrates. The type of bond among monomeric units of the carbohydrates is a factor that interferes with their digestion rate. Sucrose is a sugar that is easily hydrolyzed ( $\alpha 1,2$-bond) by digestive enzymes producing a fast release of glucose into the blood. Isomaltulose (extracted from beet - Palatinose ${ }^{\mathrm{mm}}$ ) is an isolated and modified sugar, with a bond between glucose and fructose in alpha 1,6. This bond is more stable than the sucrose alpha 1,2 bond, being slowly digested by enzymes. In the case of starch, its digestibility can be modulated by inhibition of digestive enzymes with natural ingredients such as anthocyanins, technology and by different cooking methods applied to cereal products, which result in varying degrees of starch digestion - which would be the case of the quickly digested starch from extruded cereals. In the case of digestion-RS, Nugent (2005) states that this resistance can be modified by physical means, changing the different types of known RS - which would be the case of grinding, chewing (RS1), processing and cooking (RS2), and processing conditions (RS3), which can be taken advantage of by the food industry.

\subsection{Influence of Isomaltulose (Palatinose ${ }^{T M}$ ) on postprandial metabolic regulation and substrate oxidation}

Low glycemic carbohydrates providing a slow glucose release have been shown to have an impact on postprandial glucose levels, energy providing systems, fat oxidation as well as satiety and adipose tissue accretion (Holub et al., 2010), which has also been demonstrated with the ingestion of isomaltulose by type 2 diabetes patients (Sridonpai et al., 2016).

Isomaltulose (Palatinose $\left.\mathrm{e}^{\mathrm{m}}\right)$ is a disaccharide with glucose and fructose linked by an alpha-1,6-glycosidic bond. The low GI of Palatinose ${ }^{\mathrm{mt}}$ of 32 is due to the slow hydrolysis of the alpha-1,6-glycosidic bond by the sucrase-isomaltase complex situated on the brush border membrane of the small intestinal cells (Lina et al., 2002).

Therefore, the rate of absorption of Palatinose ${ }^{\mathrm{m}} \mathrm{is}$ rather slow. Nevertheless, following hydrolysis, the resulting monosaccharides glucose and fructose are efficiently taken up and it has been 
shown that Palatinose ${ }^{\mathrm{Tw}}$ is a fully digestible carbohydrate (Holub et al., 2010; Lina et al., 2002). Altogether, low glycemic carbohydrates will lead to a longer postprandial energy supply by carbohydrates associated with a lower peak glycemic response. It is important to highlight that isomaltulose provides the same energy content ( $8 \mathrm{~kJ}$ or $4 \mathrm{kcal} / \mathrm{g}$ ) provided by sucrose, however, in a balanced manner due to the slow release of glucose in the intestines increased of glycemia resulting from rapidly absorbed carbohydrates is avoided (Brunner et al., 2012; Holub et al., 2010)

It has been demonstrated by several groups that a lower GI in meals is associated with a higher postprandial fat oxidation in healthy subjects (Wee et al., 2005). Considering obese subjects, the ingestion of isomaltulose with a lipid-rich meal also improved the profile of triglycerides and free fatty acids (FFA) in addition to the effects on postprandial glycemia (Suklaew et al., 2015). This effect can mainly be attributed to lower insulin concentrations which will lead to enhanced peripheral lipolysis, increased plasma FFA and increased $\beta$-oxidation in skeletal muscles (Stevenson et al., 2006; Tsintzas \& Williams, 1998).

The organism has huge metabolic flexibility to switch between fat or carbohydrate utilization. The amount and the GI of ingested carbohydrates is an important regulator of fuel utilization. With respect to physical exercise, the effect of low GI carbohydrates could be used to improve training gain in endurance type of sports and to spare glycogen, thereby minimizing the ergolytic effects of carbohydrate depletion (Tsintzas \& Williams, 1998). Glycogen sparing means that an increased fat oxidation during intense, prolonged endurance exercise reduces the relative proportion of carbohydrate oxidation. The lower rate of carbohydrate oxidation will preserve the intramuscular and intrahepatic glycogen stores. These stores can be used in the later stages of exercise and prevent premature fatigue.

Interventions targeted to optimize fat oxidation could also be of relevance to reduce the incidence and prevalence of metabolic diseases such as overweight, the metabolic syndrome or type 2 diabetes mellitus (Konig et al., 2012). The capacity to mobilize and oxidize fat has shown to be impaired in obese (Zurlo et al., 1990) and postobese subjects (Lean \& James, 1988). Most recently, it has been demonstrated that also in obese subjects with insulin resistance and the metabolic syndrome, the partial substitution of higher glycemic carbohydrates in foods and drinks by a low GI carbohydrate (Palatinose ${ }^{\mathrm{Tw}}$ ) resulted in a higher postprandial fat oxidation at rest and during physical activity (Konig et al., 2012). It has been hypothesized that this increased fat oxidation may confer further benefits with respect to long-term weight management and also for an improvement in metabolic risk factors (Konig et al., 2012).

In conclusion, the evidence so far suggests that fully digestible low glycemic carbohydrates with a slow glucose release induce:

1. Long-term elevated postprandial glucose levels without high postprandial glucose and insulin concentrations;

2. Higher rate of fat oxidation relative to the amount of carbohydrates consumed;

3. Prolonged energy and improved muscular performance and endurance capacity.

\subsection{Slowly digestible starch}

The use of SDS as an ingredient may contribute to the reduction of NCDs and chemical, physical, enzymatic and/or genetic industrial processes can create SDS by forming crystalline and double helices structures (Miao et al., 2015). SDS can be selected due to a higher amylose to amylopectin ratio and/or by using processes that best preserve the botanical structure of the grain and the starch crystalline structure (e.g., limiting gelatinization and/or favoring retrogradation (Lehmann \& Robin, 2007). SDS prepared from physically modified rice starches showed greater thermal stability which increases its potential of use in food industry processing (Tian et al., 2017).

In vitro digestibility characteristics of starchy foods can be evaluated thanks to the Englyst method: the glucose fraction is divided into RAG and SAG to reflect the likely rate of release and absorption of glucose (Englyst et al., 1992). Thus SDS is defined as carbohydrates that are likely to be completely digested in the small intestine but at a slower rate. However, it has not always predicted in vivo physiological starch digestibility.

In regards to their potential impact on glycemic response, several metabolic effects of high-SDS products have been explored (Vinoy et al., 2016). When comparing the effect of two breakfasts differing in SDS content (23\% versus $1.5 \%)$ in healthy subjects, Vinoy et al. (Vinoy et al., 2013) showed that glycemic and insulinemic responses were significantly reduced following the high-SDS breakfast. Using stable isotope of glucose, the authors showed that the high-SDS breakfast was shown to significantly reduce the appearance of exogenous glucose in first part for the morning and prolong its release in the late phase of the morning (Vinoy et al., 2013). SDS content appears as an important parameter to be considered in the modulation of $\mathrm{RaE}$ (rate of appearance of exogenous glucose) and glycemic response for metabolic control throughout morning.

In a study carried out with 38 overweight subjects ingested a Low GI diet or a High GI diet (Nazare et al., 2009) for 5 weeks. They were asked to modify all their starchy food products accordingly to fit their group (High or Low) and they were provided a high-SDS or low-SDS cereal breakfast every morning. Although, the high-SDS breakfast resulted in a lower appearance of exogenous glucose (evidenced by using glucose stable isotopes), the associated lower insulin response induced a lower compensatory inhibition of endogenous glucose production and of glucose uptake. Consequently, thanks to these regulatory mechanisms, glycemia was lower after the high-SDS breakfast but at a lesser extent than the difference obtained for plasma exogenous glucose appearance. Moreover, glycemic response at the subsequent standardized lunch was reduced within the high-SDS group suggesting that the modulation by SDS of glucose availability at breakfast was a determinant of glucose tolerance at lunch and all day long. Interestingly, after the 5 weeks of a LGI diet with high SDS breakfast, these effects were maintained (Nazare et al., 2009).

In another study carried out in 10 healthy subjects, the ingestion of a pasta meal high in SDS (10\%) significantly slowed down the appearance of exogenous glucose in plasma but resulted in an overall similar postprandial glycemic response (Eelderink et al., 
2012b). In this study, Eelderink and colleagues observed that, following the ingestion of pasta with high-SDS content, the reduction of the rate of appearance of glucose resulted in lower GIP (gastric inhibitory polypeptide) concentration and lower insulin response. Consequently, the rate of glucose clearance from plasma was reduced and counteracted the reduced appearance to produce a similar glycemic response. This highlights that glycemia does not always reflect the in vivo digestion rate of a starchy product and that other underlying metabolic processes that occur simultaneously may counteract the slower rate of absorption. Indeed, it has been suggested that the prolonged glucose release following SDS ingestion induced a late postprandial elevation of gut hormones (GIP and GLP-1) that may have physiological consequences regarding the second meal effect by acting on satiety of gastric emptying (Wachters-Hagedoorn et al., 2006).

Eelderink proposed that a certain low threshold for appearance of exogenous glucose reduction would be necessary to induce a sufficient effect on overall glycemia. It also highlights the potential beneficial effect of SDS that could still reduce insulin demand from pancreas and reduce subsequent risk of hypoglycemia, even if it is not linked with a parallel reduction in glycemia (Eelderink et al., 2012b). To go further to investigate the relationship between starch digestibility and insulin sensitivity, the comprehensive paper from Blaak et al. (2012) reviewed findings from studies on postprandial glycemia. Observational studies showed that diets with decreased glycemic response were associated with lower risk of diabetes, through potential mechanisms involving a decrease insulin secretion, an impact of postprandial lipid metabolism, the role of incretins/gut hormones, a reduction of gluco- and lipotoxicity (liver, pancreas, muscle). Although intervention studies have shown a positive impact of the reduction of postprandial glycemic response, there is insufficient data to conclude specifically on SDS considering the limited number of studies. Moreover, not all of them provide sufficient information regarding the precise postprandial profiling, the impact of the type of subjects and the levels and type of meal manipulation. There is still a need for longer-term well-designed interventions to identify the best profile of postprandial glycemic response for improving insulin sensitivity.

It has also been proposed that SDS could impact indirectly on insulin sensitivity by acting on lipid metabolism. Indeed, a 5 -week high-SDS diet in overweight subjects was shown to induce a significant larger weight loss associated to an improvement in fasting lipid profile compared to low-SDS diet (Zoetendal et al., 2006). An elegant study from Harbis et al. investigated the effect a high-SDS breakfast on postprandial lipemia in subjects with central obesity but not dyslipidemic (Harbis et al., 2004). The ingestion of the high-SDS biscuits blunted the increases in post-meal triglycerides and reduced the accumulation of hepatically and intestinally derived triglyceride-rich lipoproteins (triglycerides, ApoB 100 and ApoB 48). This is of high interest regarding the known relationship between postprandial lipemia and hypertriglyceridemia for the risk of type 2 diabetes. Longer studies are needed to further investigate the concomitant impact on insulin sensitivity itself.

To briefly review the other potential metabolic effects of SDS, it has been suggested that SDS may impact satiety and cognitive function through their effect on glycemic response. Regarding satiety, one hypothesis is that the SDS-linked reduction in glycemic excursion and subsequent depression in glucose and insulin would induce a prolonged satiety. However the results from few available studies remained inconclusive and the interaction with other parameters have to be clarified (Peters et al., 2011; Sands et al., 2009).

As for the relationship between GI, carbohydrates, cognitive and mental performance, two recent reviews have concluded similarly on inconclusive overall results (Ooi et al., 2011; Philippou \& Constantinou, 2014).

In conclusion, products containing high levels of SDS have been shown to slow the appearance of exogenous glucose in plasma, decrease acute glycemic response integrating their effects in insulin secretion, stimulation of gut hormones and endogenous glucose production and may prolong the postprandial phase. Longer term studies are needed to confirm the potential beneficial effects of SDS in glucose metabolism and cardiometabolic risk profile.

\subsection{Resistant starch}

According to Englyst et al. (1992), resistant starch (RS), which resists the action of digestive enzymes, is divided into 4types according to its characteristics:

- RS1: physically inaccessible starch, present in partially crushed cereal and legume grains, has its strength reduced by grinding and by chewing;

- RS2: native or non-gelatinized starch granules, resistant to hydrolysis by alpha-amylase, present in raw potatoes, unripe bananas and starches with high amylose concentration. They undergo changes in concentration according to the food processing or cooking procedures they are submitted to;

- RS3: retrograded starch, which can come from potatoes, bread, cooked and cooled corn flakes and other products submitted to prolonged or repetitive heat treatment;

- RS4: chemically modified starch, which is not naturally found in food, is only found in foods and beverages to which it has been added to. This type was reported by (Topping \& Clifton, 2001).

Starch consists of a mixture of two polysaccharides: amylose and amylopectin. Amylose is a linear polymer composed of D-glucose units in alpha 1,4 bonds and amylopectin is a branched polymer composed of D-glucose units in alpha 1,4 and alpha 1,6 bonds. Generally, starch contains about $25 \%$ amylose, but ratios vary according to the source and degree of ripeness. Common cornstarch has about $28 \%$ amylose and cornstarch with a high amylose content can have $50-70 \%$ of the polymer. Digestive enzymes act on the end of starch chains - the reducing ends. The more branched the chain is, the more action sites will be available for the enzymes to act on and thus amylopectin molecules are digested faster than amylose (Damodaran et al., 2010). 
Over the last few years, new proposals for the definition of RS type 5 have emerged. One of these proposals aims to classify the starch that interacts with lipids and both amylose and long amylopectin chains form helical complexes with fatty acids (Ai et al., 2013; Jane \& Robyt, 1984). These structures hinder the action of amylase and the amylose-lipid complex may encompass amylopectin molecules, restricting the "swelling" of starch granules and enzymatic hydrolysis (Hasjim et al., 2010; Seneviratne \& Biliaderis, 1991). Furthermore, these structures have the ability of re-complexing after heating (Birt et al., 2013). Another proposal is that resistant maltodextrins could be classified as RS5 (Fuentes-Zaragoza et al., 2010).

The ability of RS to reduce the glycemic response is under study and although the evaluation methods vary, there is evidence of this effect in short-term trials with healthy volunteers (Anderson et al., 2010; Behall et al., 1988; Menezes et al., 2010; Robertson et al., 2003), as well as the ability to reduce fasting insulin (Van Amelsvoort \& Weststrate, 1992) and also increase its sensitivity (Robertson et al., 2003). Haub et al. (2010) compared the effect of the ingestion of a single dose of RS2 (HAM-RS2) and of RS4 with respect to dextrose (solution containing $30 \mathrm{~g}$ ), and found that the glycemic response was lower for the two types of RS, but the response to RS4 was significantly lower than that the response to RS2. However, when two new types of RS4 were compared in relation to dextrose (solution with $50 \mathrm{~g}$ ), there was no difference in glycemic response (Haub et al., 2012).

In studies with prolonged ingestion of RS2 (4 to 12 weeks) of cornstarch with a high amylose content, it is possible to see that the effects on glucose homeostasis are not uniform. A study with a daily intake of $12 \mathrm{~g}$ RS2 over 6 weeks showed no changes in fasting plasma glucose and insulin, or in the indices calculated from these values (Penn-Marshall et al., 2010), while in other studies the increase in insulin sensitivity can be seen (Johnston et al., 2010; Maki et al., 2012; Robertson, 2012) (Chart 1).

RS sources can be used as an ingredient in foods and may be responsible for some physiological effects. Among them are the ingredients made from unripe banana (Tribess et al., 2009). In rats, the daily intake of unripe banana mass (UBM) or isolated unripe banana starch (UBS) for 28 days caused a reduction of insulin secretion for the same amount of plasma

Chart 1. Studies on the prolonged ingestion of Resistant Starch (RS) and glucose homeostasis in humans.

\begin{tabular}{|c|c|c|c|c|c|}
\hline Volunteers & RS type & Study design & Dose & $\begin{array}{l}\text { Impact on glucose } \\
\text { homeostasis }\end{array}$ & Authors \\
\hline Healthy & $\begin{array}{l}\text { RS2 high amylose } \\
\text { content } v s . \text { Placebo }\end{array}$ & $\begin{array}{l}\mathrm{n}=12 \\
\text { Acute }\end{array}$ & $\begin{array}{l}\text { Bread containing } \\
\text { different } \% \text { of RS }\end{array}$ & $\begin{array}{l}\text { Decreased } \mathrm{AUC}^{4}, \\
\text { glucose peak and peak } \\
\text { of insulin secretion }\end{array}$ & Ekström et al. (2013) \\
\hline Healthy & $\begin{array}{l}\text { RS2 high amylose } \\
\text { content } v s . \text { Placebo }\end{array}$ & $\begin{array}{c}\mathrm{n}=10 \\
\text { Parallel } \\
4 \text { weeks }\end{array}$ & 30 g/day & Increased IS ${ }^{5}$ & Robertson et al. (2005) \\
\hline Healthy & UBF vs. placebo & $\begin{array}{c}\mathrm{n}=11 \\
\text { Parallel } \\
6 \text { weeks }\end{array}$ & $\begin{array}{c}8 \mathrm{~g} / \text { day } \\
3 \text { times a week }\end{array}$ & $\begin{array}{l}\text { Improvement observed } \\
\text { in: } \\
\text { - Fasting insulin, } \\
\text { - HOMA IR }{ }^{6} \\
\end{array}$ & Sardá et al. (2016) \\
\hline $\mathrm{MS}^{1}$ & $\begin{array}{l}\text { RS2 high amylose } \\
\text { content } v s . \text { Placebo }\end{array}$ & $\begin{array}{c}\mathrm{n}=10 \\
\text { Single blind. Parallel } \\
12 \text { weeks }\end{array}$ & $\begin{array}{c}40 \text { g/day } \\
\text { (in } 2 \text { sachets) }\end{array}$ & $\begin{array}{l}\text { IS }^{5} \text { measured by } \\
\text { glucose Clamp } \\
\text { increased } 19 \% \text { in the } \\
\text { RS group ( } \mathrm{p}=0.023) . \\
\text { IS dropped } 14 \% \text { in the } \\
\text { placebo group and was } \\
\text { not significant }\end{array}$ & Johnston et al. (2010) \\
\hline Obese $\mathrm{MS}^{1}$ & $\begin{array}{l}\text { RS2 high amylose } \\
\text { content } v s . \text { Placebo }\end{array}$ & $\begin{array}{c}\mathrm{M}=11, \mathrm{~W}=22 \\
\text { Double Blind. Crossover. } \\
4 \text { wk. treatment and } 3 \mathrm{wk} . \\
\text { washout }\end{array}$ & $15 \mathrm{~g} /$ day (in 2 sachets) & $\begin{array}{l}\text { - Improved IS } 5 \text { in men } \\
\text { - No change observed } \\
\text { in women }\end{array}$ & Maki et al. (2012) \\
\hline $\mathrm{MS}^{1}$ & $\begin{array}{l}\text { RS2 high amylose } \\
\text { content } v s \text {. Placebo }\end{array}$ & $\begin{array}{c}\mathrm{M}=8, \mathrm{~W}=7 \\
\text { Single Blind. Crossover } \\
8 \text { week treatment and } 8 \text { week } \\
\text { washout }\end{array}$ & $40 \mathrm{~g} /$ day (in 2 sachets) & $\begin{array}{l}\text { Improvement in: } \\
\text { - Fasting glucose, } \\
\text { - Fasting insulin } \\
\text { - HOMA IR }\end{array}$ & Robertson et al. (2012) \\
\hline $\mathrm{IR}^{2}$ & $\begin{array}{l}\text { RS2 high amylose } \\
\text { content } v s . \text { Placebo }\end{array}$ & $\begin{array}{c}\text { IS }(\mathrm{n}=9), \text { IR }(\mathrm{n}=14) \\
\text { Double Blind. Crossover } \\
4 \text { week treatment and } 4 \text { week } \\
\text { washout }\end{array}$ & 30 g/day (biscuits) & $\begin{array}{l}\text { Improved IS }{ }^{5} \text { only in } \\
\text { the IR group. }\end{array}$ & Gower et al. (2016) \\
\hline $\mathrm{DT}^{3}$ (stable) & $\begin{array}{l}\text { RS2 high amylose } \\
\text { content } v s . \text { Placebo }\end{array}$ & $\mathrm{n}=17$ & $\begin{array}{l}\text { Cross-over } \\
12 \mathrm{wk} \text {. } \\
40 \mathrm{~g} / \text { day }\end{array}$ & $\begin{array}{l}\text { No change observed: } \\
\text { in IS; Fasting glucose; } \\
\text { HOMA (AUC: } \\
p=0.036 \text { ) }\end{array}$ & Bodinham et al. (2014) \\
\hline
\end{tabular}

${ }^{1} \mathrm{MS}=$ Metabolic Syndrome; ${ }^{2} \mathrm{IR}=$ Insulin Resistance; ${ }^{3} \mathrm{DT} 2=$ Type 2 Diabetes; ${ }^{4} \mathrm{AUC}=$ Area Under the Curve; ${ }^{5} \mathrm{IS}=$ Insulin Sensitivity; ${ }^{6} \mathrm{HOMA}=\mathrm{Homeostatic}$ Model Assessment; $\mathrm{RS}=$ resistant starch; $\mathrm{UBF}=$ unripe banana flour. 
glucose, and simultaneously an increase of SCFA was observed in cecal material (Dan et al., 2015). Cereal bars with UBF were tested with healthy volunteers and revealed a low-GI and low glycemic load (Santos, 2010).

Studies of regular consumption of unripe banana flour (UBF) by healthy volunteers, demonstrated impact on glucose homeostasis, satiety and intestinal function (Dan, 2011; Giuntini et al., 2015; Sardá et al., 2016). The impact on intestinal microbiota was observed mainly in a cluster of healthy volunteers with microbiome prevalent in Prevotella, indicating that the UBF has positive attributes to help reduce the risk of NCDs (Sardá, 2015).

\subsection{Food properties and processing related to GI}

Postprandial glucose responses of starch can be altered by processing conditions, as disrupting the cell wall, structure of the granule and gelatinization increases the glycemic index (Fernandes et al., 2005).

Potato and its products produced variable glycemic responses, depending on potato cultivars, maturity, starch structure, processing method and extend. GI of potatoes may be significantly reduced by manipulating the genotype of exotic potato cultivars and the development of potato genotypes with high amylose content. (Nayak et al., 2014).

Optimizing the food processing conditions can reduce the GI of potato. For example, precooking and reheating or consuming processed potatoes in cold condition may result in reduced glycemic responses. Conditions known to decrease the digestibility of potato starch and subsequent GI responses are those which decrease the starch gelatinization, increase lipid-amylose formation and increase starch retro-gradation during cooling and storage (Nayak et al., 2014). Fried potatoes of the Monalisa cultivar were pre-cooked and frozen for 24 hours and for 30 days, and longer freezing time reduced the glycemic index (Vasconcelos et al., 2015).

In the brewing process, the degree of processing of the flour used, fermentation and the preparation / cooking time will influence its glycemic response (Lau et al., 2015) and nutritional quality (Dewettinck et al., 2008). Jenkins et al. (1988) and Fardet et al. (2006) observed that breads with a higher proportion of whole grains have slower digestion and are more efficient in reducing postprandial blood glucose. In an in vitro study with loaves added with different ratios of bran and with different particle sizes, Sanz-Penella et al. (2014) observed that the higher the proportion of bran and the bigger the grain size, the lower the GI.

Two systematic reviews have evaluated pasta consumption and concluded that these foods have a low glycemic response. Pasta intake, along with the consumption of low GI foods, may contribute to the reduction of body weight (Chiavaroli et al., 2018), but more studies are needed to evaluate the relationship between the masses and the reduction of risk of cardiovascular diseases (Huang et al., 2017). Different types of pasta elicit varied glycemic responses, but always smaller in relation to white bread and potatoes. This is due to a more compact structure, as a function of the extrusion process and manufacturing techniques, which hinders the hydrolysis of the starch, and thus a delay in gastric emptying and digestion occurs. In addition, it is common to use durum wheat in the manufacture of pasta, which maintains the aleurone layer, which also keeps the content of micronutrients and protein, which in turn may contribute to the reduction of glycemic response (Huang et al., 2017; Chiavaroli et al., 2018).

\section{International regulatory panorama}

The use of dietary fiber content claims is regulated in a very diversified manner across countries, some such as Brasil (2016) and the Mercosur (Brasil, 2012) claim functional properties, and others such as the Food and Drug Administration (FDA) (Food and Drug Administration, 2013), Japan (Tanaka et al., 2004), Canada (Health-Canada, 2012) and Europe (European Union, 2012, 2013) make health claims.

In contrast, the discussion of the use of claims with the properties of slowly digested carbohydrates and of resistant starch compared to glucose response is more recent. The Scientific Panel on Dietetic Products, Nutrition and Allergies of the European Food Safety Authority (EFSA) issued a favorable opinion for the replacement of available starch in foods with high content of carbohydrates for RS2 (from high content amylose maize between $50 \%$ and $90 \%$ ), which has the ability to reduce the postprandial glycemic response when the starch available in high content carbohydrate foods is replaced. The Scientific Panel concluded that there is a cause-effect relationship between the intake of RS, from any source, when it replaces the available starch in bakery foods, and a reduction in postprandial glycemic response (European Food Safety Authority, 2011a).

Regarding SDS the EFSA issued a favorable opinion (European Food Safety Authority, 2011a), which states that "cereal products rich in slowly digestible starch provide a smaller postprandial blood glucose increase than a product with low content of slowly digestible starch" and following that the use of the claim was authorized (European Union, 2013).

Health claims for the replacement of sugar for, for example, isomaltulose regarding the reduction of postprandial glycemic responses were recommended by EFSA Panel on Dietetic Products Nutrition and Allergies (European Food Safety Authority, 2011c) and later adopted (European Union, 2012).

In Brazil, functional property claims for dietary fiber, resistant dextrin, fructo-oligosaccharides (FOS), inulin, polydextrose, lactulose, partially hydrolyzed guar gum focused on bowel function, and beta-glucans focused on lowering cholesterol have been authorized; however, no claim stating a beneficial aspect for the control of blood glucose has been authorized (Brasil, 2016).

\section{Final considerations}

Glycemic response and the resulting release of insulin are related to the type and quality of carbohydrates in foods, which can be slowly or rapidly digestible available carbohydrates or unavailable carbohydrates, depending on the rate of digestion/absorption. High postprandial glycemia in the nondiabetic population is a known universal mechanism for the progression of NCDs. 
When the target of the population is to reduce the postprandial glycemic response with no disproportional increase in insulin response, foods and/or ingredients that have the following characteristics should be selected: - low GI, GL or glycemic response; - high content of slowly digestible carbohydrate; - high content of unavailable carbohydrate or dietary fiber.

Authorized communication of the benefits of products that contain these ingredients on their labels and in the media could encourage greater use of available ingredients and/or technology with the purpose of developing products that do not result in a sharp increase in blood glucose and/or postprandial insulin levels. This can contribute to the reduction of the development NCDs and in turn reduce the costs relating to these diseases, although, longer term studies are needed to confirm the potential beneficial effects of slowly digestible carbohydrates on cardiometabolic risk profile and on general health.

\section{References}

Ai, Y., Hasjim, J., \& Jane, J. L. (2013). Effects of lipids on enzymatic hydrolysis and physical properties of starch. Carbohydrate Polymers, 92(1), 120-127. http://dx.doi.org/10.1016/j.carbpol.2012.08.092. PMid:23218274.

American Diabetes Association - ADA. (2013). Economic costs of diabetes in the U.S. in 2012. Diabetes Care, 36(4), 1033-1046. http:// dx.doi.org/10.2337/dc12-2625. PMid:23468086.

Anderson, G. H., Cho, C. E., Akhavan, T., Mollard, R. C., Luhovyy, B. L., \& Finocchiaro, E. T. (2010). Relation between estimates of cornstarch digestibility by the Englyst in vitro method and glycemic response, subjective appetite, and short-term food intake in young men. The American Journal of Clinical Nutrition, 91(4), 932-939. http://dx.doi. org/10.3945/ajcn.2009.28443. PMid:20164321.

Augustin, L. S. A., Kendall, C. W. C., Jenkins, D. J. A., Willett, W. C., Astrup, A., Barclay, A. W., Björck, I., Brand-Miller, J. C., Brighenti, F., Buyken, A. E., Ceriello, A., La Vecchia, C., Livesey, G., Liu, S., Riccardi, G., Rizkalla, S. W., Sievenpiper, J. L., Trichopoulou, A., Wolever, T. M., Baer-Sinnott, S., \& Poli, A. (2015). Glycemic index, glycemic load and glycemic response: an International Scientific Consensus Summit from the International Carbohydrate Quality Consortium (ICQC). Nutrition, Metabolism, and Cardiovascular Diseases, 25(9), 795-815. http://dx.doi.org/10.1016/j.numecd.2015.05.005. PMid:26160327.

Bahia, L. R., Araujo, D. V., Schaan, B. D., Dib, S. A., Negrato, C. A., Leão, M. P., Ramos, A. J., Forti, A. C., Gomes, M. B., Foss, M. C., Monteiro, R. A., Sartorelli, D., \& Franco, L. J. (2011). The costs of type 2 diabetes mellitus outpatient care in the Brazilian public health system. Value in Health, 14(5, Suppl 1), S137-S140. http://dx.doi. org/10.1016/j.jval.2011.05.009. PMid:21839888.

Bahia, L., Coutinho, E. S., Barufaldi, L. A., Abreu, G. A., Malhão, T. A., Souza, C. P., \& Araujo, D. V. (2012). The costs of overweight and obesity-related diseases in the Brazilian public health system: cross-sectional study. BMC Public Health, 12(1), 440. http://dx.doi. org/10.1186/1471-2458-12-440. PMid:22713624.

Barclay, A. W., Petocz, P., McMillan-Price, J., Flood, V. M., Prvan, T., Mitchell, P., \& Brand-Miller, J. C. (2008). Glycemic index, glycemic load, and chronic disease risk: a meta-analysis of observational studies. The American Journal of Clinical Nutrition, 87(3), 627-637. http://dx.doi.org/10.1093/ajcn/87.3.627. PMid:18326601.

Behall, K. M., Scholfield, D. J., \& Canary, J. (1988). Effect of starch structure on glucose and insulin responses in adults. The American
Journal of Clinical Nutrition, 47(3), 428-432. http://dx.doi.org/10.1093/ ajcn/47.3.428. PMid:3279746.

Bellmann, S., Minekus, M., Sanders, P., Bosgra, S., \& Havenaar, R. (2018). Human glycemic response curves after intake of carbohydrate foods are accurately predicted by combining in vitro gastrointestinal digestion with in silico kinetic modeling. Clinical Nutrition Experimental, 17, 8-22. http://dx.doi.org/10.1016/j.yclnex.2017.10.003.

Bindels, L. B., Delzenne, N. M., Cani, P. D., \& Walter, J. (2015). Towards a more comprehensive concept for prebiotics. Nature Reviews, Gastroenterology \& Hepatology, 12(5), 303-310. http://dx.doi. org/10.1038/nrgastro.2015.47. PMid:25824997.

Birt, D. F., Boylston, T., Hendrich, S., Jane, J. L., Hollis, J., Li, L., McClelland, J., Moore, S., Phillips, G. J., Rowling, M., Schalinske, K., Scott, M. P., \& Whitley, E. M. (2013). Resistant starch: promise for improving human health. Advances in Nutrition, 4(6), 587-601. http://dx.doi.org/10.3945/an.113.004325. PMid:24228189.

Blaak, E. E., Antoine, J. M., Benton, D., Bjorck, I., Bozzetto, L., Brouns, F., Diamant, M., Dye, L., Hulshof, T., Holst, J. J., Lamport, D. J., Laville, M., Lawton, C. L., Meheust, A., Nilson, A., Normand, S., Rivellese, A. A., Theis, S., Torekov, S. S., \& Vinoy, S. (2012). Impact of postprandial glycaemia on health and prevention of disease. Obesity Reviews, 13(10), 923-984. http://dx.doi.org/10.1111/j.1467789X.2012.01011.x. PMid:22780564.

Bodinham, C. L., Smith, L., Thomas, E. L., Bell, J. D., Swann, J. R., Costabile, A., Russell-Jones, D., Umpleby, A. M., \& Robertson, M. D. (2014). Efficacy of increased resistant starch consumption in human type 2 diabetes. Endocrine Connections, 3(2), 75-84. http:// dx.doi.org/10.1530/EC-14-0036. PMid:24671124.

Brasil, Ministério da Saúde, Agência Nacional de Vigilância Sanitária - ANVISA. (2012, November 13). Dispõe sobre o Regulamento Técnico sobre Informação Nutricional Complementar (Resolução $\mathrm{RDC}^{\circ} 54$ de 12 de novembro de 2012). Diário Oficial [da] República Federativa do Brasil.

Brasil, Ministério da Saúde, Agência Nacional de Saúde Suplementar - ANS. (2015). Vigitel Brasil 2014: vigilância de fatores de risco e proteção para doenças crônicas por inquérito telefônico. Brasília: ANS.

Brasil, Ministério da Saúde, Agência Nacional de Vigilância Sanitária ANVISA. (2016). Alimentos com alegações de propriedades funcionais e ou de saúde. Brasília: ANVISA. Retrieved from: http://portal. anvisa.gov.br/alimentos/alegacoes

Brouns, F., Bjorck, I., Frayn, K. N., Gibbs, A. L., Lang, V., Slama, G., \& Wolever, T. M. S. (2005). Glycaemic index methodology. Nutrition Research Reviews, 18(1), 145-171. http://dx.doi.org/10.1079/ NRR2005100. PMid:19079901.

Brunner, S., Holub, I., Theis, S., Gostner, A., Melcher, R., Wolf, P., Amann-Gassner, U., Scheppach, W., \& Hauner, H. (2012). Metabolic effects of replacing sucrose by isomaltulose in subjects with type 2 diabetes: a randomized double-blind trial. Diabetes Care, 35(6), 1249-1251. http://dx.doi.org/10.2337/dc11-1485. PMid:22492584.

Buyken, A. E., Mitchell, P., Ceriello, A., \& Brand-Miller, J. (2010). Optimal dietary approaches for prevention of type 2 diabetes: a life-course perspective. Diabetologia, 53(3), 406-418. http://dx.doi. org/10.1007/s00125-009-1629-8. PMid:20049415.

Carreira, M. C., Lajolo, F. M., \& Menezes, E. W. (2004). Glycemic index: effect of food storage under low temperature. Brazilian Archives of Biology and Technology, 47(4), 569-574. http://dx.doi.org/10.1590/ S1516-89132004000400010.

Chiavaroli, L., Kendall, C. W. C., Braunstein, C. R., Blanco Mejia, S., Leiter, L. A., Jenkins, D. J. A., \& Sievenpiper, J. L. (2018). Effect of pasta in the context of low-glycaemic index dietary patterns on body weight and markers of adiposity: a systematic review and 
meta-analysis of randomised controlled trials in adults. BMJ Open, 8(3), e019438. http://dx.doi.org/10.1136/bmjopen-2017-019438. PMid:29615407.

Chiu, C. J., Liu, S., Willett, W. C., Wolever, T. M., Brand-Miller, J. C., Barclay, A. W., \& Taylor, A. (2011). Informing food choices and health outcomes by use of the dietary glycemic index. Nutrition Reviews, 69(4), 231-242. http://dx.doi.org/10.1111/j.1753-4887.2011.00382.x. PMid:21457267.

Cummings, J. H., \& Stephen, A. M. (2007). Carbohydrate terminology and classification. European Journal of Clinical Nutrition, 61(Suppl 1), S5-S18. http://dx.doi.org/10.1038/sj.ejcn.1602936. PMid:17992187.

Damodaran, S., Parkin, K. L., \& Fennema, O. R. (2010). Química de alimentos de Fennema. Porto Alegre: Artmed.

Dan, M. C. T. (2011). Avaliação da potencialidade da farinha de banana verde como ingrediente funcional: estudo in vivo e in vitro (Tese de doutorado). Universidade de São Paulo, São Paulo.

Dan, M. C. T., Cardenette, G. H., Sardá, F. A., Giuntini, E. B., BelloPérez, L. A., Carpinelli, Â., Lajolo, F. M., \& Menezes, E. W. (2015). Colonic fermentation of unavailable carbohydrates from unripe banana and its influence over glycemic control. Plant Foods for Human Nutrition, 70(3), 297-303. http://dx.doi.org/10.1007/s11130015-0493-6. PMid:26092708.

Dewettinck, K., Van Bockstaele, F., Kühne, B., Van de Walle, D., Courtens, T. M., \& Gellynck, X. (2008). Nutritional value of bread: influence of processing, food interaction and consumer perception. Journal of Cereal Science, 48(2), 243-257. http://dx.doi.org/10.1016/j. jcs.2008.01.003.

Eelderink, C., Moerdijk-Poortvliet, T. C., Wang, H., Schepers, M., Preston, T., Boer, T., Vonk, R. J., Schierbeek, H., \& Priebe, M. G. (2012a). The glycemic response does not reflect the in vivo starch digestibility of fiber-rich wheat products in healthy men. The Journal of Nutrition, 142(2), 258-263. http://dx.doi.org/10.3945/ jn.111.147884. PMid:22223569.

Eelderink, C., Schepers, M., Preston, T., Vonk, R. J., Oudhuis, L., \& Priebe, M. G. (2012b). Slowly and rapidly digestible starchy foods can elicit a similar glycemic response because of differential tissue glucose uptake in healthy men. The American Journal of Clinical Nutrition, 96(5), 1017-1024. http://dx.doi.org/10.3945/ajcn.112.041947. PMid:22990033.

Ekström, L. M., Björck, I. M., \& Ostman, E. M. (2013). On the possibility to affect the course of glycaemia, insulinaemia, and perceived hunger/ satiety to bread meals in healthy volunteers. Food \& Function, 4(4), 522-529. http://dx.doi.org/10.1039/c2fo30251a. PMid:23334658.

Englyst, H. N., \& Hudson, G. J. (1996). The classification and measurement of dietary carbohydrates. Food Chemistry, 57(1), 15-21. http://dx.doi. org/10.1016/0308-8146(96)00056-8.

Englyst, H. N., Kingman, S. M., \& Cummings, J. H. (1992). Classification and measurement of nutritionally important starch fractions. European Journal of Clinical Nutrition, 46(Suppl 2), S33-S50. PMid:1330528.

Englyst, K. N., Englyst, H. N., Hudson, G. J., Cole, T. J., \& Cummings, J. H. (1999). Rapidly available glucose in foods: an in vitro measurement that reflects the glycemic response. The American Journal of Clinical Nutrition, 69(3), 448-454. http://dx.doi.org/10.1093/ajcn/69.3.448. PMid:10075329.

Englyst, K. N., Liu, S., \& Englyst, H. N. (2007). Nutritional characterization and measurement of dietary carbohydrates. European Journal of Clinical Nutrition, 61(Suppl 1), S19-S39. http://dx.doi.org/10.1038/ sj.ejcn.1602937. PMid:17992185.

Englyst, K. N., Vinoy, S., Englyst, H. N., \& Lang, V. (2003). Glycaemic index of cereal products explained by their content of rapidly and slowly available glucose. British Journal of Nutrition, 89(3), 329-340. http://dx.doi.org/10.1079/BJN2002786. PMid:12628028.

European Food Safety Authority - EFSA. (2011a). Scientific Opinion on the substantiation of a health claim related to slowly digestible starch in starch-containing foods and reduction of post-prandial glycaemic responses, 9 C.F.R. Parma: EFSA.

European Food Safety Authority - EFSA. (2011b). Scientific Opinion on the substantiation of health claims related to sugar replacers and maintenance of tooth mineralisation and reduction of post-prandial glycaemic responses, 9 C.F.R. Parma: EFSA.

European Food Safety Authority - EFSA. (2011c). EFSA Panel on Dietetic Products Nutrition and Allergies. Scientific Opinion on the substantiation of health claims related to the sugar replacers xylitol, sorbitol, mannitol, maltitol, lactitol, isomalt, erythritol, D-tagatose, isomaltulose, sucralose and polydextrose and maintenance of tooth mineralisation by decreasing tooth demineralisation (ID 463, 464, $563,618,647,1182,1591,2907,2921,4300)$, and reduction of post-prandial glycaemic responses (ID 617, 619, 669, 1590, 1762, 2903, 2908, 2920) pursuant to Article 13(1) of Regulation (EC) No 1924/2006. EFSA Journal, 9(4), 2076. http://dx.doi.org/10.2903/j. efsa.2011.2076.

European Union - EU. (2012, May 25). Establishing a list of permitted health claims made on foods, other than those referring to the reduction of disease risk and to children's development and health (EU Commission Regulation No 432/2012 of 16 May 2012). Official Journal of the European Union.

European Union - EU. (2013, September 4). Authorising certain health claims made on foods, other than those referring to the reduction of disease risk and to children's development and health and amending Regulation (EU) No 432/2012 (EU Commission Regulation No 851/2013 of 3 September 2013). Official Journal of the European Union.

Fardet, A., Leenhardt, F., Lioger, D., Scalbert, A., \& Rémésy, C. (2006). Parameters controlling the glycaemic response to breads. Nutrition Research Reviews, 19(1), 18-25. http://dx.doi.org/10.1079/NRR2006118. PMid:19079873.

Fernandes, G., Velangi, M., \& Wolever, T. (2005). Glycemic index of potatoes commonly consumed in North America. Journal of the American Dietetic Association, 105(4), 557-562. http://dx.doi. org/10.1016/j.jada.2005.01.003. PMid:15800557.

Ferrannini, E., Gastaldelli, A., Miyazaki, Y., Matsuda, M., Mari, A., \& DeFronzo, R. A. (2005). Beta-cell function in subjects spanning the range from normal glucose tolerance to overt diabetes: a new analysis. The Journal of Clinical Endocrinology and Metabolism, 90(1), 493-500. http://dx.doi.org/10.1210/jc.2004-1133. PMid:15483086.

Food and Agriculture Organization of the United Nations - FAO. (2003). Food energy: methods of analysis and conversion factors. Report of a technical workshop (FAO Food and Nutrition Paper, No. 77). Rome: FAO.

Food and Agriculture Organization of the United Nations - FAO. (2008). FAO technical meeting on prebiotics: Advance Analytical Technologies. Rome: FAO. Retrieved from http://studylib.net/doc/18387443/faotechnical-meeting-on-prebiotics---aat

Food and Agriculture Organization of the United Nations - FAO, World Health Organization - WHO. (1998). Carbohydrates in human nutrition: report of a joint FAO/WHO expert consultation, April 14-18, 1997. Rome: FAO.

Food and Drug Administration - FDA. (2013). Guidance for industry: a food labeling guide: 10. Appendix B: additional requirements for nutrient content claims). Silver Spring: FDA. Retrieved from https://www.fda.gov/ 
Food/GuidanceRegulation/GuidanceDocumentsRegulatoryInformation/ LabelingNutrition/ucm064916.htm

Forbes, J. M., \& Cooper, M. E. (2013). Mechanisms of diabetic complications. Physiological Reviews, 93(1), 137-188. http://dx.doi. org/10.1152/physrev.00045.2011. PMid:23303908.

Fuentes-Zaragoza, E., Riquelme-Navarrete, M. J., Sánchez-Zapata, E., \& Pérez-Álvarez, J. A. (2010). Resistant starch as functional ingredient: a review. Food Research International, 43(4), 931-942. http://dx.doi. org/10.1016/j.foodres.2010.02.004.

Gallus, S., Lugo, A., Murisic, B., Bosetti, C., Boffetta, P., \& La Vecchia, C. (2015). Overweight and obesity in 16 European countries. European Journal of Nutrition, 54(5), 679-689. http://dx.doi.org/10.1007/ s00394-014-0746-4. PMid:25091048.

Garsetti, M., Vinoy, S., Lang, V., Holt, S., Loyer, S., \& Brand-Miller, J. C. (2005). The glycemic and insulinemic index of plain sweet biscuits: relationships to in vitro starch digestibility. Journal of the American College of Nutrition, 24(6), 441-447. http://dx.doi.org/10.1080/073 15724.2005.10719489. PMid:16373940.

Giuntini, E. B., Sardá, F. A. H., Lui, M. C. Y., Tadini, C. C., Lajolo, F. M., \& Menezes, E. W. (2015). Gastrointestinal hormone modulation after a double-blind interventional study with unavailable carbohydrates. Food Research International, 77(Part 1), 17-23. http://dx.doi. org/10.1016/j.foodres.2015.04.003.

Goff, L. M., Cowland, D. E., Hooper, L., \& Frost, G. S. (2013). Low glycaemic index diets and blood lipids: a systematic review and meta-analysis of randomised controlled trials. Nutrition, Metabolism, and Cardiovascular Diseases, 23(1), 1-10. http://dx.doi.org/10.1016/j. numecd.2012.06.002. PMid:22841185.

Goñi, I., Garcia-Alonso, A., \& Saura-Calixto, F. (1997). A starch hydrolysis procedure to estimate glycemic index. Nutrition Research, 17(3), 427-437. http://dx.doi.org/10.1016/S0271-5317(97)00010-9.

Gower, B. A., Bergman, R., Stefanovski, D., Darnell, B., Ovalle, F., Fisher, G., Sweatt, S. K., Resuehr, H. S., \& Pelkman, C. (2016). Baseline insulin sensitivity affects response to high-amylose maize resistant starch in women: a randomized, controlled trial. Nutrition \& Metabolism, 13(1), 2. http://dx.doi.org/10.1186/s12986-016-00625. PMid:26766961.

Gunnerud, U. J., Heinzle, C., Holst, J. J., Ostman, E. M., \& Bjorck, I. M. (2012). Effects of pre-meal drinks with protein and amino acids on glycemic and metabolic responses at a subsequent composite meal. PLoS One, 7(9), e44731. http://dx.doi.org/10.1371/journal. pone.0044731. PMid:23028596.

Harbis, A., Perdreau, S., Vincent-Baudry, S., Charbonnier, M., Bernard, M. C., Raccah, D., Senft, M., Lorec, A. M., Defoort, C., Portugal, H., Vinoy, S., Lang, V., \& Lairon, D. (2004). Glycemic and insulinemic meal responses modulate postprandial hepatic and intestinal lipoprotein accumulation in obese, insulin-resistant subjects. The American Journal of Clinical Nutrition, 80(4), 896-902. http://dx.doi. org/10.1093/ajcn/80.4.896. PMid:15447896.

Harvard School of Public Health - HSPH. (2013). The nutrition source carbohydrates and the glycemic load. Boston: HSPH.

Hasjim, J., Lee, S.-O., Hendrich, S., Setiawan, S., Ai, Y., \& Jane, J. (2010). Characterization of a Novel Resistant-starch and its effects on postprandial plasma-glucose and insulin responses. Cereal Chemistry Journal, 87(4), 257-262. http://dx.doi.org/10.1094/ CCHEM-87-4-0257.

Haub, M. D., Hubach, K. L., Al-Tamimi, E. K., Ornelas, S., \& Seib, P. A. (2010). Different types of resistant starch elicit different glucose reponses in humans. Journal of Nutrition and Metabolism, 2010, 230501. http://dx.doi.org/10.1155/2010/230501. PMid:20700404.
Haub, M. D., Louk, J. A., \& Lopez, T. C. (2012). Novel resistant potato starches on glycemia and satiety in humans. Journal of Nutrition and Metabolism, 2012, 478043. http://dx.doi.org/10.1155/2012/478043. PMid:22655177.

Health-Canada - HC. (2012). Policy for labelling and advertising of dietary fibre: containing food products. bureau of nutritional sciences. food directorate, health products and food branch. Canada: HC. Retrieved from http://www.hc-sc.gc.ca/ fn-an/legislation/pol/ fibre-label-etiquetage-eng.php

Holub, I., Gostner, A., Theis, S., Nosek, L., Kudlich, T., Melcher, R., \& Scheppach, W. (2010). Novel findings on the metabolic effects of the low glycaemic carbohydrate isomaltulose (Palatinose). British Journal of Nutrition, 103(12), 1730-1737. http://dx.doi.org/10.1017/ S0007114509993874. PMid:20211041.

Huang, M., Li, J., Há, M. A., Riccardi, G., \& Liu, S. (2017). A systematic review on the relations between pasta consumption and cardio-metabolic risk factors. Nutrition, Metabolism, and Cardiovascular Diseases, 27(11), 939-948. http://dx.doi.org/10.1016/j.numecd.2017.07.005. PMid:28954707.

Jane, J., \& Robyt, J. F. (1984). Structure studies of amylose-V complexes and retrograded amylose by action of alpha amylases, and a new method for preparing amylodextrins. Carbohydrate Research, 132(1), 105-118. http://dx.doi.org/10.1016/0008-6215(84)85068-5. PMid:6435871.

Jenkins, D. J. A., Wesson, V., Wolever, T. M. S., Jenkins, A. L., Kalmusky, J., Guidici, S., Csima, A., Josse, R. G., \& Wong, G. S. (1988). Wholemeal versus wholegrain breads: proportion of whole or cracked grain and the glycaemic response. BMJ, 297(6654), 958-960. http://dx.doi. org/10.1136/bmj.297.6654.958. PMid:3142566.

Jenkins, D. J., Wolever, T. M., Taylor, R. H., Barker, H., Fielden, H., Baldwin, J. M., Bowling, A. C., Newman, H. C., Jenkins, A. L., \& Goff, D. V. (1981). Glycemic index of foods: a physiological basis for carbohydrate exchange. The American Journal of Clinical Nutrition, 34(3), 362-366. http://dx.doi.org/10.1093/ajcn/34.3.362. PMid:6259925.

Johnston, K. L., Thomas, E. L., Bell, J. D., Frost, G. S., \& Robertson, M. D. (2010). Resistant starch improves insulin sensitivity in metabolic syndrome. Diabetic Medicine, 27(4), 391-397. http:// dx.doi.org/10.1111/j.1464-5491.2010.02923.x. PMid:20536509.

Jones, J. M. (2014). CODEX-aligned dietary fiber definitions help to bridge the 'fiber gap'. Nutrition Journal, 13(1), 34. http://dx.doi. org/10.1186/1475-2891-13-34. PMid:24725724.

Klosterbuer, A., Roughead, Z. F., \& Slavin, J. (2011). Benefits of dietary fiber in clinical nutrition. Nutrition in Clinical Practice, 26(5), 625635. http://dx.doi.org/10.1177/0884533611416126. PMid:21947646.

Kolb, H., \& Mandrup-Poulsen, T. (2010). The global diabetes epidemic as a consequence of lifestyle-induced low-grade inflammation. Diabetologia, 53(1), 10-20. http://dx.doi.org/10.1007/s00125-0091573-7. PMid:19890624.

Konig, D., Theis, S., Kozianowski, G., \& Berg, A. (2012). Postprandial substrate use in overweight subjects with the metabolic syndrome after isomaltulose (Palatinose) ingestion. Nutrition, 28(6), 651-656. http://dx.doi.org/10.1016/j.nut.2011.09.019. PMid:22264450.

Lajolo, F. M., \& Menezes, E. W. (2006). Carbohidratos en alimentos regionales ibero-americanos. São Paulo: EDUSP.

Lau, E., Soong, Y. Y., Zhou, W., \& Henry, J. (2015). Can bread processing conditions alter glycaemic response? Food Chemistry, 173, 250-256. http://dx.doi.org/10.1016/j.foodchem.2014.10.040. PMid:25466020.

Laville, M., Vors, C., Nazare, J. A., \& Michalski, M. C. (2013). Intérêt de la phase postprandiale pour la santé de l'homme. Bulletin de l’Académie Nationale de Médecine, 197(1), 65-77. PMid:24672980. 
Lean, M. E., \& James, W. P. (1988). Metabolic effects of isoenergetic nutrient exchange over 24 hours in relation to obesity in women. International Journal of Obesity, 12(1), 15-27. PMid:3360561.

Lehmann, U., \& Robin, F. (2007). Slowly digestible starch: its structure and health implications: a review. Trends in Food Science \& Technology, 18(7), 346-355. http://dx.doi.org/10.1016/j.tifs.2007.02.009.

Ley, S. H., Hamdy, O., Mohan, V., \& Hu, F. B. (2014). Prevention and management of type 2 diabetes: dietary components and nutritional strategies. Lancet, 383(9933), 1999-2007. http://dx.doi.org/10.1016/ S0140-6736(14)60613-9. PMid:24910231.

Li, Q., Blume, S. W., Huang, J. C., Hammer, M., \& Graf, T. R. (2015). The economic burden of obesity by glycemic stage in the United States. PharmacoEconomics, 33(7), 735-748. http://dx.doi.org/10.1007/ s40273-014-0248-5. PMid:25564434.

Licht, T. R., Ebersbach, T., \& Frøkiær, H. (2012). Prebiotics for prevention of gut infections. Trends in Food Science \& Technology, 23(2), 70-82. http://dx.doi.org/10.1016/j.tifs.2011.08.011.

Lina, B. A. R., Jonker, D., \& Kozianowski, G. (2002). Isomaltulose (Palatinose ${ }^{\oplus}$ ): a review of biological and toxicological studies. Food and Chemical Toxicology, 40(10), 1375-1381. http://dx.doi. org/10.1016/S0278-6915(02)00105-9. PMid:12387299.

Liu, S., Manson, J. E., Stampfer, M. J., Hu, F. B., Giovannucci, E., Colditz, G. A., Hennekens, C. H., \& Willett, W. C. (2000). A prospective study of whole-grain intake and risk of type 2 diabetes mellitus in US women. American Journal of Public Health, 90(9), 1409-1415. http://dx.doi.org/10.2105/AJPH.90.9.1409. PMid:10983198.

Livesey, G. (2003). Health potential of polyols as sugar replacers, with emphasis on low glycaemic properties. Nutrition Research Reviews, 16(2), 163-191. http://dx.doi.org/10.1079/NRR200371. PMid:19087388.

Livesey, G., Taylor, R., Livesey, H., \& Liu, S. (2013). Is there a doseresponse relation of dietary glycemic load to risk of type 2 diabetes? Meta-analysis of prospective cohort studies. The American Journal of Clinical Nutrition, 97(3), 584-596. http://dx.doi.org/10.3945/ ajcn.112.041467. PMid:23364021.

Ludwig, D. S. (2003). Glycemic load comes of age. The Journal of Nutrition, 133(9), 2695-2696. http://dx.doi.org/10.1093/jn/133.9.2695. PMid:12949351.

Maki, K. C., Pelkman, C. L., Finocchiaro, E. T., Kelley, K. M., Lawless, A. L., Schild, A. L., \& Rains, T. M. (2012). Resistant starch from high-amylose maize increases insulin sensitivity in overweight and obese men. The Journal of Nutrition, 142(4), 717-723. http://dx.doi. org/10.3945/jn.111.152975. PMid:22357745.

Menezes, E. W., \& Lajolo, F. M. (1995). Utilização do amido de leguminosas. Archivos Latinoamericanos de Nutricion, 45(1), S270-S272.

Menezes, E. W., Dan, M. C., Cardenette, G. H., Goñi, I., Bello-Pérez, L. A., \& Lajolo, F. M. (2010). In vitro colonic fermentation and glycemic response of different kinds of unripe banana flour. Plant Foods for Human Nutrition, 65(4), 379-385. http://dx.doi.org/10.1007/s11130010-0190-4. PMid:20839056.

Menezes, E. W., Giuntini, E. B., Dan, M. C., Sardá, F. A., \& Lajolo, F. M. (2013). Codex dietary fibre definition: justification for inclusion of carbohydrates from 3 to 9 degrees of polymerisation. Food Chemistry, 140(3), 581-585. http://dx.doi.org/10.1016/j.foodchem.2013.02.075. PMid:23601410.

Miao, M., Jiang, B., Cui, S. W., Zhang, T., \& Jin, Z. (2015). Slowly digestible starch: a review. Critical Reviews in Food Science and Nutrition, 55(12), 1642-1657. http://dx.doi.org/10.1080/10408398 .2012.704434. PMid:24915311.
Nantel, G. (2003). Glycemic carbohydrate: an international perspective. Nutrition Reviews, 61(5 Pt 2, Suppl 5), S34-S39. http://dx.doi. org/10.1301/nr.2003.may.S34-S39. PMid:12828190.

Nayak, B., De J. Berrios, J., \& Tang, J. (2014). Impact of food processing on the glycemic index (GI) of potato products. Food Research International, 56, 35-46. http://dx.doi.org/10.1016/j.foodres.2013.12.020.

Nazare, J. A., Normand, S., Oste Triantafyllou, A., Brac de la Perriere, A., Desage, M., \& Laville, M. (2009). Modulation of the postprandial phase by beta-glucan in overweight subjects: effects on glucose and insulin kinetics. Molecular Nutrition \& Food Research, 53(3), 361369. http://dx.doi.org/10.1002/mnfr.200800023. PMid:18837470.

Normand, S., Khalfallah, Y., Louche-Pelissier, C., Pachiaudi, C., Antoine, J. M., Blanc, S., Desage, M., Riou, J. P., \& Laville, M. (2001). Influence of dietary fat on postprandial glucose metabolism (exogenous and endogenous) using intrinsically (13)C-enriched durum wheat. British Journal of Nutrition, 86(1), 3-11. http://dx.doi.org/10.1079/ BJN2001359. PMid:11432759.

Nugent, A. P. (2005). Health properties of resistant starch. Nutrition Bulletin, 30(1), 27-54. http://dx.doi.org/10.1111/j.1467-3010.2005.00481.x.

Ooi, C. P., Loke, S. C., Yassin, Z., \& Hamid, T. A. (2011). Carbohydrates for improving the cognitive performance of independent-living older adults with normal cognition or mild cognitive impairment. Cochrane Database of Systematic Reviews, 13(4), CD007220. PMid:21491398.

Penn-Marshall, M., Holtzman, G. I., \& Barbeau, W. E. (2010). African americans may have to consume more than 12 grams a day of resistant starch to lower their risk for type 2 diabetes. Journal of Medicinal Food, 13(4), 999-1004. http://dx.doi.org/10.1089/jmf.2009.0195. PMid:20482275.

Peters, H. P. F., Ravestein, P., van der Hijden, H. T. W. M., Boers, H. M., \& Mela, D. J. (2011). Effect of carbohydrate digestibility on appetite and its relationship to postprandial blood glucose and insulin levels. European Journal of Clinical Nutrition, 65(1), 47-54. http://dx.doi. org/10.1038/ejcn.2010.189. PMid:20842170.

Philippou, E., \& Constantinou, M. (2014). The influence of glycemic index on cognitive functioning: a systematic review of the evidence. Advances in Nutrition, 5(2), 119-130. http://dx.doi.org/10.3945/ an.113.004960. PMid:24618754.

Riccardi, G., Rivellese, A. A., \& Giacco, R. (2008). Role of glycemic index and glycemic load in the healthy state, in prediabetes, and in diabetes. The American Journal of Clinical Nutrition, 87(1), 269S-274S. http://dx.doi.org/10.1093/ajcn/87.1.269S. PMid:18175767.

Roberfroid, M., Gibson, G. R., Hoyles, L., McCartney, A. L., Rastall, R., Rowland, I., Wolvers, D., Watzl, B., Szajewska, H., Stahl, B., Guarner, F., Respondek, F., Whelan, K., Coxam, V., Davicco, M. J., Léotoing, L., Wittrant, Y., Delzenne, N. M., Cani, P. D., Neyrinck, A. M., \& Meheust, A. (2010). Prebiotic effects: metabolic and health benefits. British Journal of Nutrition, 104(Suppl 2), S1-S63. http:// dx.doi.org/10.1017/S0007114510003363. PMid:20920376.

Robertson, M. D. (2012). Dietary-resistant starch and glucose metabolism. Current Opinion in Clinical Nutrition and Metabolic Care, 15(4), 362-367. http://dx.doi.org/10.1097/MCO.0b013e3283536931. PMid:22510681.

Robertson, M. D., Bickerton, A. S., Dennis, A. L., Vidal, H., \& Frayn, K. N. (2005). Insulin-sensitizing effects of dietary resistant starch and effects on skeletal muscle and adipose tissue metabolism. The American Journal of Clinical Nutrition, 82(3), 559-567. http://dx.doi. org/10.1093/ajcn/82.3.559. PMid:16155268.

Robertson, M. D., Currie, J. M., Morgan, L. M., Jewell, D. P., \& Frayn, K. N. (2003). Prior short-term consumption of resistant starch enhances postprandial insulin sensitivity in healthy subjects. Diabetologia, 
46(5), 659-665. http://dx.doi.org/10.1007/s00125-003-1081-0. PMid:12712245.

Robertson, M. D., Wright, J. W., Loizon, E., Debard, C., Vidal, H., Shojaee-Moradie, F., Russell-Jones, D., \& Umpleby, A. M. (2012). Insulin-sensitizing effects on muscle and adipose tissue after dietary fiber intake in men and women with metabolic syndrome. The Journal of Clinical Endocrinology and Metabolism, 97(9), 3326-3332. http:// dx.doi.org/10.1210/jc.2012-1513. PMid:22745235.

Rosella, L. C., Lebenbaum, M., Fitzpatrick, T., O’Reilly, D., Wang, J., Booth, G. L., Stukel, T. A., \& Wodchis, W. P. (2016). Impact of diabetes on health care costs in a population-based cohort: a cost analysis. Diabetic Medicine, 33(3), 395-403. http://dx.doi.org/10.1111/ dme.12858. PMid:26201986.

Rosin, P. M., Lajolo, F. M., \& Menezes, E. W. (2002). Measurement and characterization of dietary starches. Journal of Food Composition and Analysis, 15(4), 367-377. http://dx.doi.org/10.1006/jfca.2002.1084.

Salmerón, J., Manson, J. E., Stampfer, M. J., Colditz, G. A., Wing, A. L., \& Willett, W. C. (1997). Dietary fiber, glycemic load, and risk of non-insulin-dependent diabetes mellitus in women. Journal of the American Medical Association, 277(6), 472-477. http://dx.doi. org/10.1001/jama.1997.03540300040031. PMid:9020271.

Sands, A. L., Leidy, H. J., Hamaker, B. R., Maguire, P., \& Campbell, W. W. (2009). Consumption of the slow-digesting waxy maize starch leads to blunted plasma glucose and insulin response but does not influence energy expenditure or appetite in humans. Nutrition Research, 29(6), 383-390. http://dx.doi.org/10.1016/j. nutres.2009.05.009. PMid:19628104.

Santos, J. F. (2010). Avaliação das propriedades nutricionais de barras de cereais elaboradas com farinha de banana verde. São Paulo: Universidade de São Paulo.

Sanz-Penella, J. M., Laparra, J. M., \& Haros, M. (2014). Impact f a-amylase during breadmaking on in vitro kinetics of starch hydrolysis and glycaemic index of enriched bread with bran. Plant Foods for Human Nutrition, 69(3), 216-221. http://dx.doi.org/10.1007/s11130-0140436-7. PMid:25074672.

Sardá, F. A. H. (2015). Farinha de banana verde: efeitos fisiológicos do consumo regular sobre a fome/saciedade e microbiota intestinal em voluntários saudáveis (Tese de doutorado). Universidade de São Paulo, São Paulo.

Sardá, F. A. H., Giuntini, E. B., Gomez, M. L. P. A., Lui, M. C. Y., Negrini, J. A. E., Tadini, C. C., Lajolo, F. M., \& Menezes, E. W. (2016). Impact of resistant starch from unripe banana flour on hunger, satiety, and glucose homeostasis in healthy volunteers. Journal of Functional Foods, 24, 63-74. http://dx.doi.org/10.1016/j.jff.2016.04.001.

Saris, W. H., Asp, N. G., Bjorck, I., Blaak, E., Bornet, F., Brouns, F., Frayn, K. N., Fürst, P., Riccardi, G., Roberfroid, M., \& Vogel, M. (1998). Functional food science and substrate metabolism. British Journal of Nutrition, 80(Suppl 1), S47-S75. http://dx.doi.org/10.1079/ BJN19980105. PMid:9849354.

Schaafsma, G., \& Slavin, J. L. (2015). Significance of inulin fructans in the human diet. Comprehensive Reviews in Food Science and Food Safety, 14(1), 37-47. http://dx.doi.org/10.1111/1541-4337.12119.

Schmidt, M. I., Duncan, B. B., Silva, G. A., Menezes, A. M., Monteiro, C. A., Barreto, S. M., Chor, D., \& Menezes, P. R. (2011). Chronic non-communicable diseases in Brazil: burden and current challenges. Lancet, 377(9781), 1949-1961. http://dx.doi.org/10.1016/S01406736(11)60135-9. PMid:21561658.

Seneviratne, H. D., \& Biliaderis, C. G. (1991). Action of a-amylases on amylose-lipid complex superstructures. Journal of Cereal Science, 13(2), 129-143. http://dx.doi.org/10.1016/S0733-5210(09)80030-1.
Shrout, P., \& Fleiss, J. (1979). Intraclass correlations: uses in assessing rater reliability. Psychological Bulletin, 86(2), 420-428. http://dx.doi. org/10.1037/0033-2909.86.2.420. PMid:18839484.

Sridonpai, P., Komindr, S., \& Kriengsinyos, W. (2016). Impact of isomaltulose and sucrose based breakfasts on postprandial substrate oxidation and glycemic/insulinemic changes in type-2 diabetes mellitus subjects. Journal of the Medical Association of Thailand, 99(3), 282-289. PMid:27276739.

Stevenson, E. J., Williams, C., Mash, L. E., Phillips, B., \& Nute, M. L. (2006). Influence of high-carbohydrate mixed meals with different glycemic indexes on substrate utilization during subsequent exercise in women. The American Journal of Clinical Nutrition, 84(2), 354-360. http://dx.doi.org/10.1093/ajcn/84.2.354. PMid:16895883.

Suklaew, P.-o., Suraphad, P., Adisakwattana, S., Sirichai, S., Songchitsomboon, S., \& Mäkynen, K. (2015). The effects of isomaltulose-based beverage on postprandial plasma glucose and lipid profiles in obese men. Journal of Food Science and Agricultural Technology, 1(1), 36-39.

Tanaka, H., Kaneda, F., Suguro, R., \& Baba, H. (2004). Current system for regulation of health foods in Japan. Journal of the Japan Medical Association, 47(9), 436-450.

Tian, Y., Wang, S., Tong, Q., \& Zhan, J. (2017). Thermal and crystalline properties of slowly digestible starch prepared from the starches physically modified by $\beta$-cyclodextrins. Starch, 69(3-4), 1500370. http://dx.doi.org/10.1002/star.201500370.

Topping, D. L., \& Clifton, P. M. (2001). Short-chain fatty acids and human colonic function: roles of resistant starch and nonstarch polysaccharides. Physiological Reviews, 81(3), 1031-1064. http:// dx.doi.org/10.1152/physrev.2001.81.3.1031. PMid:11427691.

Tribess, T. B., Hernández-Uribe, J. P., Méndez-Montealvo, M. G. C., Menezes, E. W., Bello-Perez, L. A., \& Tadini, C. C. (2009). Thermal properties and resistant starch content of green banana flour (Musa cavendishii) produced at different drying conditions. Lebensmittel-Wissenschaft + Technologie, 42(5), 1022-1025. http:// dx.doi.org/10.1016/j.lwt.2008.12.017.

Tsintzas, K., \& Williams, C. (1998). Human muscle glycogen metabolism during exercise: effect of carbohydrate supplementation. Sports Medicine, 25(1), 7-23. http://dx.doi.org/10.2165/00007256-19982501000002. PMid:9458524.

Van Amelsvoort, J. M., \& Weststrate, J. A. (1992). Amylose-amylopectin ratio in a meal affects postprandial variables in male volunteers. The American Journal of Clinical Nutrition, 55(3), 712-718. http:// dx.doi.org/10.1093/ajcn/55.3.712. PMid:1550048.

Vasconcelos, N. C. M., Salgado, S. M., Livera, A. V. S., Andrade, S. A. C., Oliveira, M. G., \& Stamford, T. L. M. (2015). Influence of heat treatment on the sensory and physical characteristics and carbohydrate fractions of french-fried potatoes (Solanum tuberosum L.). Food Sci. Technol., 35(3), 561-569. http://dx.doi.org/10.1590/1678-457X.6685.

Vinoy, S., Laville, M., \& Feskens, E. (2016). Slow-release carbohydrates: growing evidence on metabolic responses and public health interest: summary of the symposium held at the 12th European Nutrition Conference (FENS 2015). Food \& Nutrition Research, 60(1), 31662. http://dx.doi.org/10.3402/fnr.v60.31662. PMid:27388153.

Vinoy, S., Normand, S., Meynier, A., Sothier, M., Louche-Pelissier, C., Peyrat, J., Maitrepierre, C., Nazare, J. A., Brand-Miller, J., \& Laville, M. (2013). Cereal processing influences postprandial glucose metabolism as well as the GI effect. Journal of the American College of Nutrition, 32(2), 79-91. http://dx.doi.org/10.1080/07315724.201 3.789336. PMid:24015715.

Wachters-Hagedoorn, R. E., Priebe, M. G., Heimweg, J. A., Heiner, A. M., Englyst, K. N., Holst, J. J., Stellaard, F., \& Vonk, R. J. (2006). The rate of intestinal glucose absorption is correlated with plasma 
glucose-dependent insulinotropic polypeptide concentrations in healthy men. The Journal of Nutrition, 136(6), 1511-1516. http:// dx.doi.org/10.1093/jn/136.6.1511. PMid:16702313.

Wee, S. L., Williams, C., Tsintzas, K., \& Boobis, L. (2005). Ingestion of a high-glycemic index meal increases muscle glycogen storage at rest but augments its utilization during subsequent exercise. Journal of Applied Physiology, 99(2), 707-714. http://dx.doi.org/10.1152/ japplphysiol.01261.2004. PMid:15831796.

World Health Organization - WHO. (2014). Global status report on noncommunicable diseases 2014. Geneve: WHO.

World Health Organization - WHO. (2016a). Global Health Observatory (GHO) data: obesity and overweigth. Geneve: WHO. Retrieved from http://www.who.int/gho/ncd/risk_factors/overweight/en/
World Health Organization - WHO. (2016b). World Health Day 2016: beat diabetes. Geneve: WHO. Retrieved from http://www.who.int/ campaigns/world-health-day/2016/en/

World Health Organization - WHO, Food and Agriculture Organization of the United Nations - FAO. (2003). Diet, nutrition and prevention of chronic diseases (WHO Technical Report Series, No. 916). Geneve: WHO.

Zoetendal, E. G., Vaughan, E. E., \& de Vos, W. M. (2006). A microbial world within us. Molecular Microbiology, 59(6), 1639-1650. http:// dx.doi.org/10.1111/j.1365-2958.2006.05056.x. PMid:16553872.

Zurlo, F., Lillioja, S., Esposito-Del Puente, A., Nyomba, B. L., Raz, I., Saad, M. F., Swinburn, B. A., Knowler, W. C., Bogardus, C., \& Ravussin, E. (1990). Low ratio of fat to carbohydrate oxidation as predictor of weight gain: study of 24-h RQ. The American Journal of Physiology, 259(5 Pt 1), E650-E657. PMid:2240203. 